\title{
Physicochemical, Mineralogical Liberation Characteristics, and Direct Recovery of Copper and Iron from Copper Electric Furnace Slag
}

\author{
Tianguo Li, Yue Liu, Shan Zhang, Ming Jiang* \\ College of Resources and Environment, Yunnan Agricultural University, Kunming 650201, PR China
}

Received: 19 February 2020

Accepted: 7 August 2020

\begin{abstract}
Recovery of valuable metal from copper electric furnace slag (CEFS) is of great interest for saving minerals and reducing pollution. XRF, XRD, mineral liberation analysis (MLA), and batch tests were conducted to investigate the mineralogical and recovery of copper and iron from CEFS. Based on the mineralogical characteristics, a flotation and magnetic combined process was proposed and evaluated for the recovery of copper and iron. The results show that copper in CEFS main distribute in chalcopyrite, copper matte, and bornite, while iron distribute in magnetite, fayalite, and pyroxene. The proposed process involves the recovery of iron via magnetic separation from flotation tailings after recovering copper from CEFS by flotation. $72.79 \%$ of copper and $20.41 \%$ of iron were recycled from CEFS where the grades of copper and iron concentrate were $19.86 \%$ and $50.69 \%$, respectively. This is a significant finding. Engineering application clearly proved that recycling copper and iron from CEFS by this combined process has significant economic, social, and environmental benefit.
\end{abstract}

Keywords: copper electric furnace slag, mineralogical characteristic, metal recycling, flotation, magnetic separation

\section{Introduction}

Large amount of copper smelting slag (CSS) is generated from copper pyrometallurgical process and discharged as industrial solid waste. According to the slag sources and characteristics, CSS can be classified into several categories like copper electric furnace slag, converter slag, reverberatory furnace slag and so on [1-2]. In a typical copper pyrometallurgical process, approximately 2.2 tons of waste CSS generated

*e-mail: mingjiang2010@163.com for every ton of copper produced [3-4]. The annual global output of CSS is an average of 25 million tons. In China, blister copper production is about 5.2 million tons, generating more than 8 million tons CSS every year $[1,5]$. At present, CSS generation reaches up to more than 50 million tons [6-7]. Waste CSS still contains large amounts of copper, iron, and other valuable metals such as nickel, cobalt, and molybdenum [8-10]. However, these valuable metals are not only mineral resources, but also heavy metal contaminants. Stockpiling or disposals of such huge quantities of slag require lager areas, and the processing sites are unavailable for land utilization [11-13]. Moreover, these slags contain high concentrations of heavy metals that 
are very harmful when toxic metals is released into the environment, causing both environmental and space occupation problems. The increase in toxic metals around slag stockpiling sites has a long-term negative effect on the biosphere and potential ecological pollution risk $[6,14-16]$. Therefore, the recovery of valuable metals from waste slags presents both economic and environmental incentives.

The conflict between massive demand for mineral resources and scarcity of mineral resources is becoming increasingly acute [17]. CSS contains a large of valuable metals and acts as a secondary resource of metals; therefore, it has received much attention in the recovery of valuable metals [18-22]. During the past two decades, attempts have been made to develop methods for metal recovery from CSS. Basically, these include several categories, namely, flotation $[4,23]$ magnetic separation [4], leaching [14, 24-28], and roasting [29-30]. Among them, physical separation including flotation and magnetic separation is one of the most simple, effective, and economical method to recover valuable metals from CSS. For copper, flotation can efficiently capture metallic $\mathrm{Cu}$ and sulfide minerals to provide a copper concentrate [31-32]. Iron mainly occurs as magnetite and iron silicate (fayalite) as well as silicates of other metals. Magnetic separation is the most common method for separating magnetic iron from other iron silicate minerals [5, 33].

Mineralogical morphology of valuable elements and distribution of target minerals are related to the use of CSS directly [1-2, 33]. Meanwhile, the particle size of crystallization of copper in the slag related to the cooling speed of slag closely [34]. In the CSS obtained after water quenching treatment, which is the most common CSS cooling method, the slag characteristics include stable chemical properties, compact structure and hardness, very fine granularity of embedded copper and iron, and difficult separation $[1,6]$. Studies have shown that the CSS slow cooling process is advantageous for the migration and accumulation of copper particles and improvement in the grind ability [34]. The inherent composition of CSS cannot be changed; therefore, its forming process can be controlled to improve flotation and magnetic mineral processing $[1,3,33]$.

In a copper-smelting plant of Yunnan Copper Co., Ltd. (Yunnan, China), approximately 0.2 million tons CEFS are abandoned annually. Metallic copper and iron contents of this slag are $0.5-0.8 \mathrm{wt} \%$ and $35-50 \mathrm{wt} \%$, respectively. The copper content of CEFS often higher than those of copper ore grades. Thus, it worth be recovered from a perspective of both economic and environmental benefits. In this study, the CEFS of this copper-smelting plant is selected as the studied slag sample. A suitable slow cooling process, mineralogical characteristics, and recovery possibility of copper and iron from CEFS through a simple physical separation process including flotation and magnetic separation were investigated. The aim of this study was to evaluate the feasibility, economic, social, and environmental value of copper and iron recovery from CEFS by flotation and magnetic separation, thus providing guidance for the resource utilization of CEFS and other slags.

\section{Material and Methods}

\section{Materials}

The CEFS used in this study was taken from a typical copper-smelting plant of Yunnan Copper Co., Ltd. The copper smelting is pyrometallurgical process to produce blister copper from copper ore and comprises the following steps in turn: oxygen-enriched top-blown smelting, slag cleaning electric furnace and converter blowing. The studied CEFS is one of the CSS, which generate from an electric furnace for cleaning the copper slag after oxygen-enriched top-blown smelting.

\section{Preparation and Experimental Process}

A flowsheet of copper and iron recovery route developed in this study is shown in Fig. 1. After smelting, the CEFS with a high temperature $\left(1200^{\circ} \mathrm{C}\right)$ is released into the slag strap to cool down. To better crystallize and regrouping of metals, the optimum cooling down of CEFS involves $24 \mathrm{~h}$ slow natural cooling, $24 \mathrm{~h}$ water spray cooling, and $8 \mathrm{~h}$ natural cooling successively. After slow cooled in copper slag dross, the CEFS was crushed by jaw crusher (C80) and cone crusher (GP100MF) in turn to make the size of CEFS all less than $350 \mathrm{~mm}, 3 \mathrm{~mm}$ respectively at a crush rule of two-stage closed-circuit. Then, a

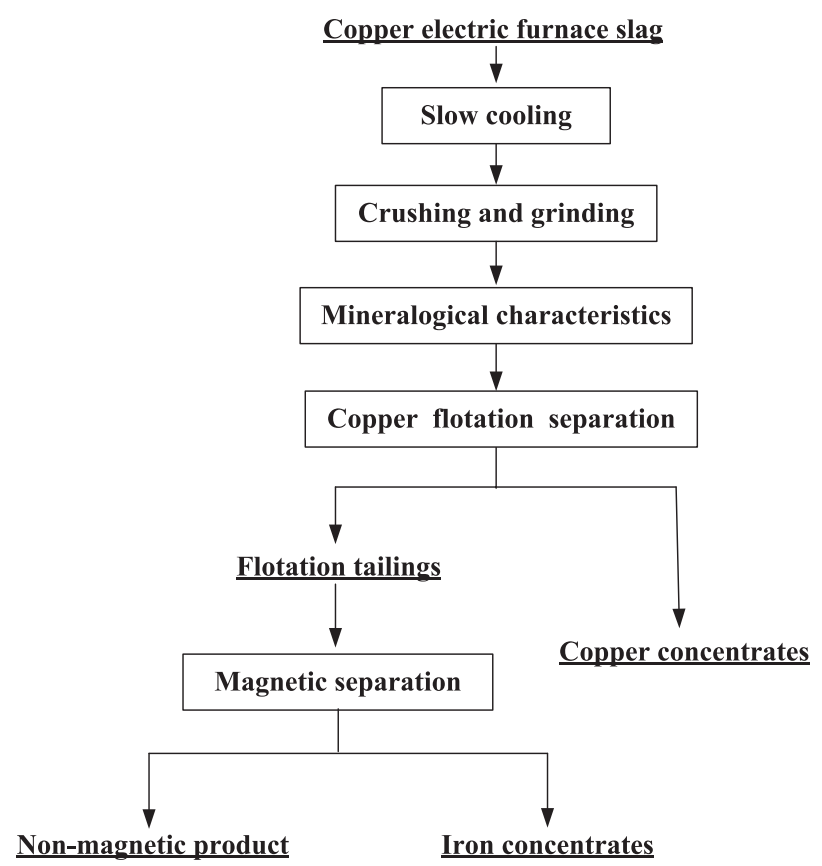

Fig. 1. Flowsheet of copper and iron recovery route developed in this study. 
Table 1. Chemical composition of the CEFS sample.

\begin{tabular}{|l|c|c|c|c|c|c|c|c|c|c|}
\hline Composition & $\mathrm{Cu}$ & $\mathrm{Fe}$ & $\mathrm{Zn}$ & $\mathrm{Pb}$ & $\mathrm{As}$ & $\mathrm{S}$ & $\mathrm{SiO}_{2}$ & $\mathrm{Al}_{2} \mathrm{O}_{3}$ & $\mathrm{CaO}$ & $\mathrm{MgO}$ \\
\hline Weight (\%) & 0.77 & 38.60 & 1.39 & 0.10 & 0.04 & 1.05 & 27.2 & 5.48 & 4.78 & 1.45 \\
\hline
\end{tabular}

two-stage wet grinding was conducted to further make the size of $75-90 \%$ CEFS less than $48 \mu \mathrm{m}(75-90 \%$, $-48 \mu \mathrm{m})$. The crushed and ground rate was about $0.78 \mathrm{t} / \mathrm{min}, 0.50 \mathrm{t} / \mathrm{min}$ respectively. The CEFS sample was well mixed and a representative samples was sampled by coning and quartering technique. These representative samples were used for the analysis of their mineralogical characteristics and recovery of copper and iron by coupling flotation and magnetic separation.

\section{Analytical Methods}

The mineralogical characteristics of minerals and chemical composition, particle size, phase distribution, mineral monomer dissociation degree, and characteristics of embedded minerals were determined by X-ray fluorescence spectrometry (XRF), X-ray diffraction (XRD, $40 \mathrm{kV}, 150 \mathrm{~mA}$ ), and mineral liberation analysis (MLA). MLA is a quantitative automated mineralogical analysis system, composed of one scanning electron microscope (SEM), two energydispersive X-ray spectrometers (EDS), and process mineralogical analysis software. MLA analysis was carried out in the XBSE measurement mode. The data processing software was MDI Jade7, and the phase retrieval database was PDF2-2004. Yield, mineral grade, and recovery rate were used to comprehensive analyze the ore dressing efficiency of copper and iron from CEFS.

\section{Results and Discussion}

\section{Mineralogical Characteristics of CEFS}

\section{Phase and Chemical Composition}

CEFS is black, and a part of clinker has obvious metallic luster, $2.0-2.4 \mathrm{~g} / \mathrm{mL}$ of loose bulk density and $3.5-4.3 \mathrm{~g} / \mathrm{mL}$ of weight density. CEFS is stable, has a dense texture, and hard (mohs hardness is 7-9 degrees). The results of a chemical analysis of the CEFS are shown in Table 1. There are $0.77 \mathrm{wt} \%$ of copper, $1.39 \mathrm{wt} \%$ of zinc, and $38.60 \mathrm{wt} \%$ of iron occurs in CEFS. It is necessary to analyze its occurrence form and the difficulty of metallic recovery.

The XRD pattern shown in Fig. 2a) showed that fayalite $\left(2 \mathrm{FeO} . \mathrm{SiO}_{2}\right)$, magnetite $\left(\mathrm{Fe}_{3} \mathrm{O}_{4}\right)$, and pyroxene $\left(\mathrm{Ca}(\mathrm{Fe}, \mathrm{Mg})\left(\mathrm{SiO}_{3}\right)_{2}\right)$ are the main crystalline substance present in the CEFS. As shown in Table 2, the main mineral composition is pyroxene, fayalite, magnetite, and copper sulphide, and their total $\mathrm{wt} \%$ is as high as $98.63 \%$. The mineral forms of copper and iron occurring in CEFS are shown in Table 3. 65.73\% copper is distributed in chalcopyrite $\left(\mathrm{CuFeS}_{2}\right)$, copper matte, and bornite $\left(\mathrm{Cu}_{5} \mathrm{FeS}_{4}\right)$. The copper grades of bornite, chalcopyrite, chalcocite, copper matte, and copper alloy are $63.31 \%, 29.04 \%, 76.14 \%, 7.85 \%$, and $71.02 \%$, respectively. Copper sulfide accounts for $85.88 \%$ of the total copper, and other $14.12 \%$ is copper oxide. Only $21.47 \%$ copper is distributed in difficultly floated minerals and gangue. This suggests that floatation is probably an effective method to recover copper from CEFS. 93.97\% iron is distributed in fayalite, magnetite, and pyroxene. Magnetic iron accounts for 54.89\% of total iron, but only $26.53 \%$ of iron is distributed in magnetite and ferroalloy. This shows that $26.53 \%$ of iron in CEFS can be easily recycled via magnetic separation, while others are difficult to separate.

\section{Size Distribution}

Size distributions of CEFS and target copper and iron minerals were analyzed after crushing and ground to $(90 \%,-48 \mu \mathrm{m})$. As shown in Fig. $2 \mathrm{~b})$, the maximum and minimum particle sizes are $150.0 \mu \mathrm{m}$ and $0.87 \mu \mathrm{m}$,
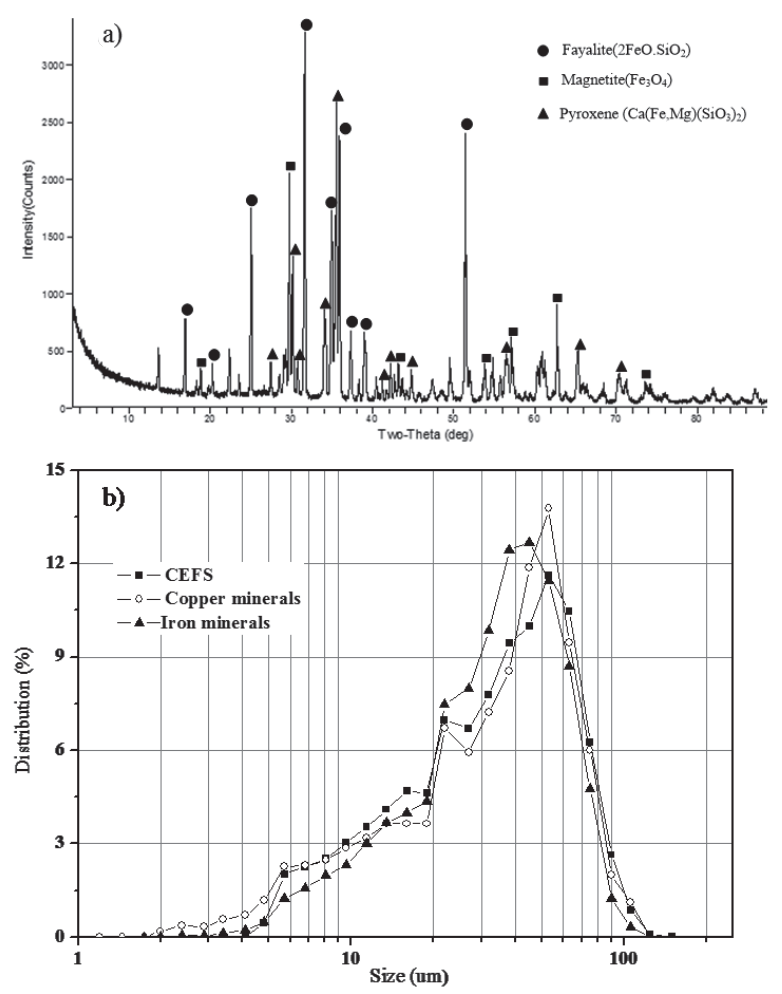

Fig. 2. a) X-ray diffraction patterns of CEFS; b) size distribution of CEFS, copper, and iron minerals. 
Table 2. Principal mineral composition of CEFS.

\begin{tabular}{|c|c|c|c|}
\hline Mineral & wt $\%$ & Mineral & wt $\%$ \\
\hline Pyroxene & 41.26 & Copper alloy & 0.039 \\
\hline Fayalite & 38.24 & Antimonide & 0.005 \\
\hline Magnetite and Ferroalloy & 15.35 & Quartz and Glass & 0.059 \\
\hline Copper matte & 3.78 & Oxides & 0.775 \\
\hline Hematite & 0.49 & Others \\
\hline
\end{tabular}

Table 3. Mineral occurrence forms of copper and iron element in CEFS.

\begin{tabular}{|c|c|c|c|c|c|}
\hline Minerals & Cu distribution (\%) & Fe distribution (\%) & Minerals & Cu distribution (\%) & Fe distribution (\%) \\
\hline Copper matte & 21.02 & 1.91 & Ferroalloy & 3.26 & 1.81 \\
\hline Bornite & 20.89 & 0.09 & Magnetite & 2.83 & 24.72 \\
\hline Chalcocite & 2.85 & & Hematite & 2.22 & 0.62 \\
\hline Chalcopyrite & 23.82 & 0.76 & Fayalite & 1.32 & 46.05 \\
\hline Copper alloy & 3.90 & & pyroxene & 11.26 & 23.20 \\
\hline Sphalerite & 0.06 & 0.02 & feldspar & 0.58 & 0.22 \\
\hline Antimonide & 0.07 & & Oxides & & 0.01 \\
\hline Galena & 0.01 & & Others & & 0.02 \\
\hline Pyrite & 5.91 & 0.55 & Total & 100 & 100 \\
\hline
\end{tabular}

respectively. Compared with the size distribution of CEFS, the grains of target mineral (copper and iron) are relatively finer. Mineral granularity larger than $100 \mu \mathrm{m}$ or smaller than $6 \mu \mathrm{m}$ is not conducive to flotation and usually affords a lower recovery rate [3536]. The results of size distribution indicate that the range of average particle size of copper minerals is suitable for separating copper by flotation.

\section{Mineral Embedded and Liberation Features}

The mineral embedded features of copper and iron ores in CEFS are shown in Fig. 3. As shown in Fig. 3(a-c), copper minerals (bornite, chalcopyrite, and copper matte) are the main interlocking and inclusion minerals in pyroxene, magnetite, and fayalite, and the mineral inclusion relationships are always complex. The binary and multiple inclusions of copper sulfide are $29.20 \%$ and $40.69 \%$, respectively. Most of the magnetite is present as interlocking and inclusion minerals in pyroxene, fayalite, and copper minerals. The percentages of binary and multiple inclusions of magnetite are $46.18 \%$ and $34.11 \%$, respectively.

Mineral liberation degrees of the target mineral of copper sulfide and magnetite are shown in Tables 4 and 5. The liberation of copper sulphide and magnetite is relatively low, only $39.02 \%$ and $34.07 \%$, respectively, and the liberation degree is higher than $80 \%$. The particle size (average diameter) is relatively smaller for minerals with a lower liberation degree. This suggests that the target minerals with elaborate embedded characteristics are more difficult to liberate. For floatation, the target mineral has been effectively exposed when the liberation degree is more than $20 \%$ and vice versa. Approximately $72.42 \%$ of copper was exposed effectively when the grinding fineness is $(90 \%,-48 \mu \mathrm{m})$. This indicates that most of the copper sulfide can be concentrated by floatation. Theoretical calculation shows that the copper grade of copper concentrate is $17.71 \%$ when the copper recovery rate is $72.42 \%$. However, the average particle size distribution of $27.58 \%$ copper sulfide, exposed inadequately or not, is about $4.28 \mu \mathrm{m}$. Because this is not suitable for floatation, even the improvement in grinding fineness made it difficult to improve the liberation and recycling effectively. For magnetite, the recovery rate of iron is only $8.60-8.71 \%$ to qualify as iron concentrate, and the iron grade is over $60 \%$. To improve the liberation degree of mineral, further increase in its grinding fineness is needed.

\section{Copper Flotation Studies}

\section{Opened Circuit Flotation Tests}

The open-circuit flotation experiment of copper roughing involved two-stage roughing and singlestage scavenging. The flotation times of roughing I\#, 


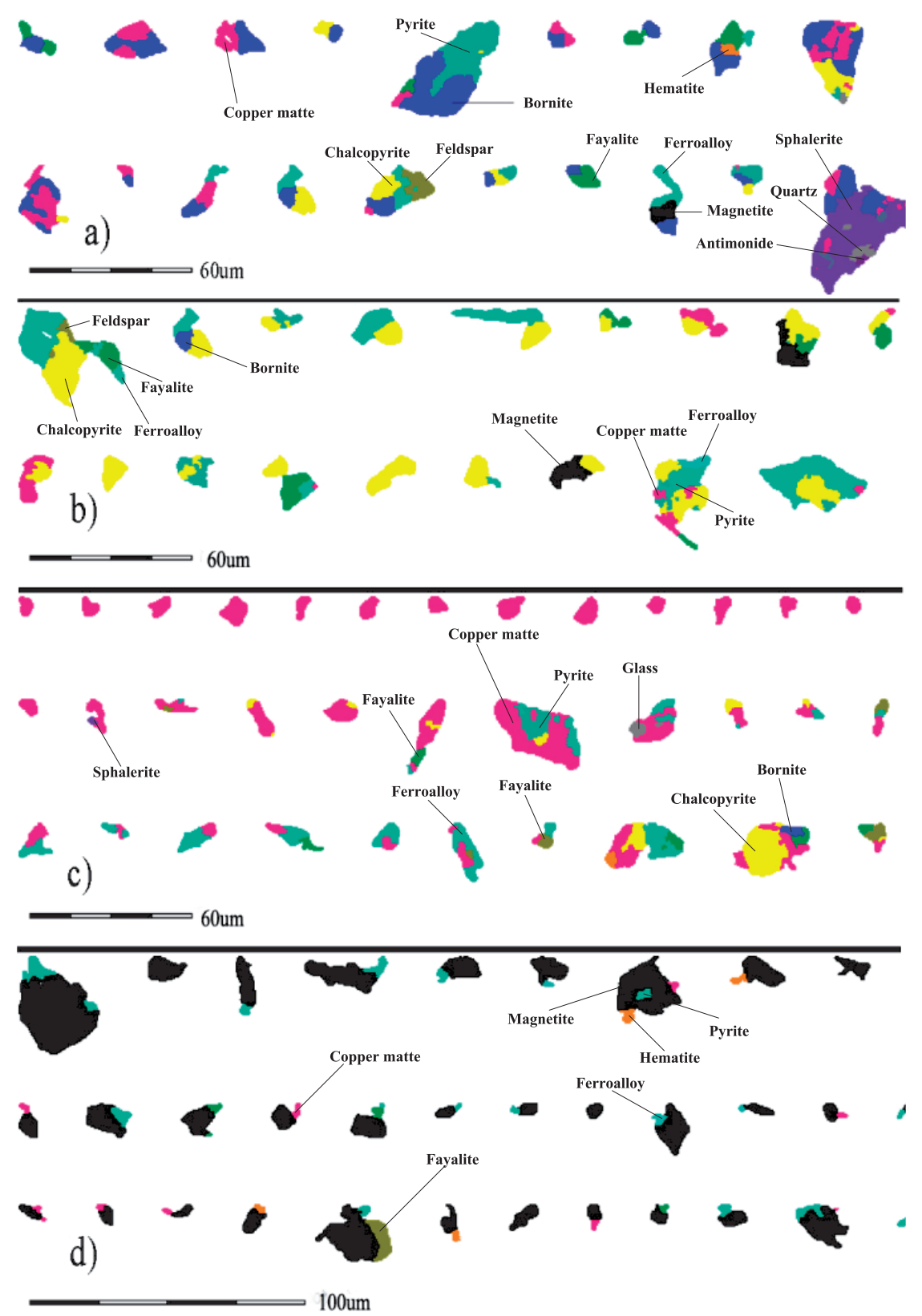

Fig. 3. Mineral interlocking and inclusions relationships and embedded features of copper and iron ores in CEFS a) Bornite, b) Chalcopyrite, c) Copper matte, and d) Magnetite.

Table 4. Mineral liberation degree of target mineral of copper sulphide.

\begin{tabular}{|c|c|c|c|}
\hline $\begin{array}{c}\text { Liberation } \\
\text { degree } \\
(\%)\end{array}$ & $\begin{array}{c}\text { Average } \\
\text { diameter } \\
(\mu \mathrm{m})\end{array}$ & $\begin{array}{c}\text { Distribution } \\
(\%)\end{array}$ & $\begin{array}{c}\text { Cumulative } \\
\text { distribution } \\
(\%)\end{array}$ \\
\hline $0 \sim 20$ & 4.28 & 27.58 & 100 \\
\hline $20 \sim 40$ & 7.73 & 12.48 & 72.42 \\
\hline $40 \sim 60$ & 11.44 & 10.49 & 59.94 \\
\hline $60 \sim 80$ & 17.46 & 10.42 & 49.44 \\
\hline $80 \sim 100$ & 26.37 & 9.81 & 39.02 \\
\hline 100 & 11.98 & 29.21 & 29.21 \\
\hline
\end{tabular}

Table 5. Mineral Liberation degree of target mineral of magnetite and ferroalloy.

\begin{tabular}{|c|c|c|c|}
\hline $\begin{array}{c}\text { Liberation } \\
\text { degree } \\
(\%)\end{array}$ & $\begin{array}{c}\text { Average } \\
\text { diameter } \\
(\mu \mathrm{m})\end{array}$ & $\begin{array}{c}\text { Distribution } \\
(\%)\end{array}$ & $\begin{array}{c}\text { Cumulative } \\
\text { distribution } \\
(\%)\end{array}$ \\
\hline $0 \sim 20$ & 8.42 & 10.90 & 100 \\
\hline $20 \sim 40$ & 13.74 & 18.35 & 89.1 \\
\hline $40 \sim 60$ & 17.98 & 17.46 & 70.76 \\
\hline $60 \sim 80$ & 22.2 & 19.23 & 53.3 \\
\hline $80 \sim 100$ & 27.06 & 18.46 & 34.07 \\
\hline 100 & 14.29 & 15.61 & 15.61 \\
\hline
\end{tabular}


a)

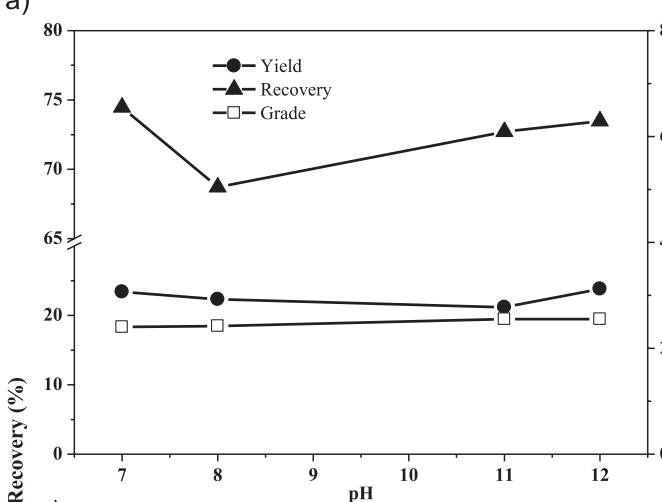

b)
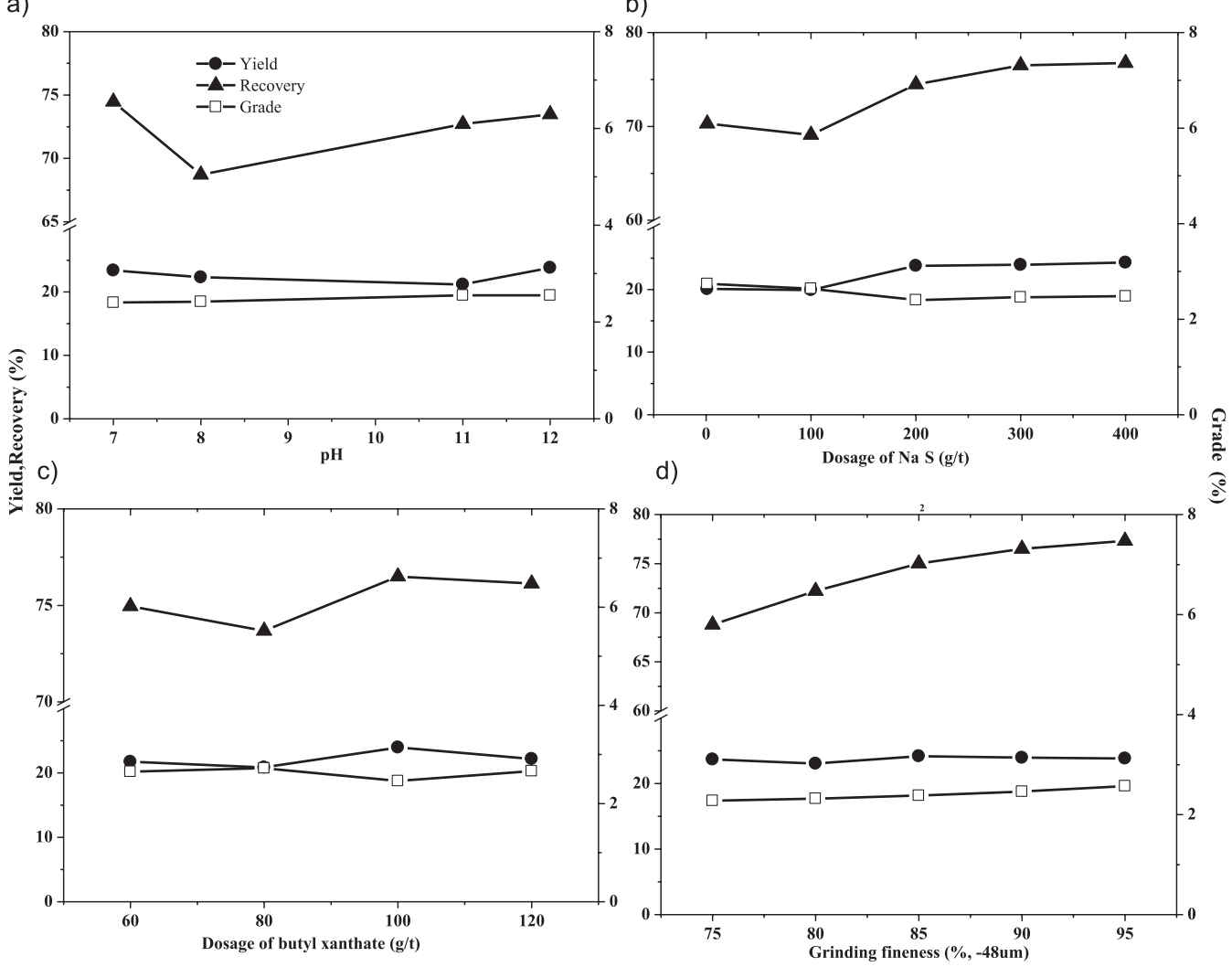

Fig. 4. Effects of main conditions and parameters for the copper roughing of CEFS flotation.

roughing II\#, and scavenging $\mathrm{I} \#$ are $8 \mathrm{~min}, 6 \mathrm{~min}$, and $6 \mathrm{~min}$, respectively. The effects of slurry $\mathrm{pH}$, dosage of sodium sulfide $\left(\mathrm{Na}_{2} \mathrm{~S}\right)$, butyl xanthate $\left(\mathrm{C}_{5} \mathrm{H}_{10} \mathrm{OS}_{2}\right)(\mathrm{BX})$, and butylamine dithiophosphate $\left(\left(\mathrm{C}_{4} \mathrm{H}_{9} \mathrm{O}\right)_{2} \mathrm{PSSNH}_{4}\right)$ (BD) on copper flotation are shown in Fig. 4. As shown in Fig. 4a), the slurry $\mathrm{pH}$ (adjusted by adding $\mathrm{CaO}$ ) significantly affects the copper recovery rate and shows the optimum value at $\mathrm{pH}$ 7. Therefore, limestone should not be added to increase the slurry pH. Fig. 4b) shows that the copper yield and recovery rate increased by about $4 \%$ and $6 \%$, respectively, when increasing the dosage of $\mathrm{Na}_{2} \mathrm{~S}$ from $0 \mathrm{~g} / \mathrm{t}$ to $400 \mathrm{~g} / \mathrm{t}$. While the copper grade of rough concentrate does not decrease significantly. This shows that addition of $\mathrm{Na}_{2} \mathrm{~S}$ is conducive to the flotation separation of copper, and $300 \mathrm{~g} / \mathrm{t}$ of $\mathrm{Na}_{2} \mathrm{~S}$ is an optimization index, because more $\mathrm{Na}_{2} \mathrm{~S}$ will increase the viscosity of bubble which is not conducive to floating. Fig. 4c) shows that the copper grade slightly changed, while the copper yield and recovery significantly increased when adding BX collector. In addition, a mixture scheme of BX and BD was investigated. The results show that the mixture of both collectors can improve the copper recovery rate. The optimum proportion of $\mathrm{BX}$ and $\mathrm{BD}$ was 1:1, and the dosages of both collectors were $50 \mathrm{~g} / \mathrm{t}$ and $50 \mathrm{~g} / \mathrm{t}$, respectively. Fig. 4d) shows that both the copper recovery rate and grade increase when improving the grinding fineness of CEFS. The proposed economic grinding fineness has a better recovery rate, and the grade is $(90 \%,-48 \mu \mathrm{m})$.
Similarly, the optimal conditions of flotation cleaning of copper rough concentrate were also investigated. The results show that the flotation cleaning process of copper rough concentrates needs three stages, and the flotation times of cleaners I\#, II\#, and III\# were $6 \mathrm{~min}$, $5 \mathrm{~min}$, and $3 \mathrm{~min}$, respectively. The optimal regulator and collector scheme was the addition of $10 \mathrm{~g} / \mathrm{t} \mathrm{BX}$ and $10 \mathrm{~g} / \mathrm{t} \mathrm{BD}$ and without $\mathrm{Na}_{2} \mathrm{~S}$. The regrinding fineness of copper rough concentrates is $(98 \%,-38 \mu \mathrm{m})$.

\section{Closed Circuit Flotation Tests}

Based on the open-circuit flotation conclusions, different flotation processing routes are discussed. The comparison results of different processing routes of CEFS copper flotation are shown in Fig. 5. Two-stage scavenging process can effectively reduce the losses of copper in flotation tailings even though the copper grade slightly decreased. The regrinding of copper rough concentrates can significantly improve both the copper recovery and grade. Comparing with the route of copper rough concentrates without regrinding, the copper recovery and grade increased by $2.40 \%$ and $3.45 \%$, respectively. These results indicate that the optimal copper flotation processing routes for CEFS are two-stage roughing, two-stage scavenging, and threestage cleaning, and copper rough concentrates needed regrinding to achieve $(98 \%,-38 \mu \mathrm{m})$. The process flow diagram and parameters are shown in Fig. 8. The copper grade and recovery of copper concentrate 


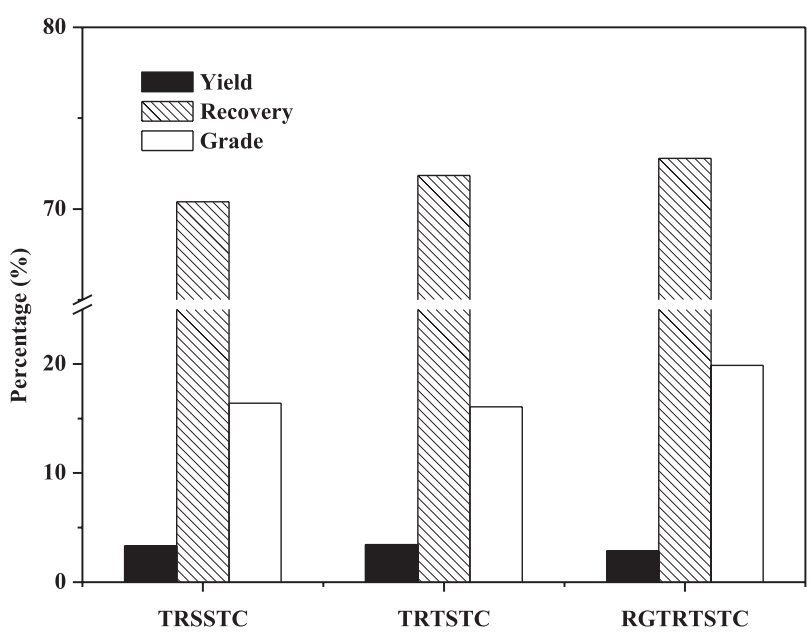

Fig. 5. Comparison result of different flotation processing routes of CEFS (in diagram, TRSSTC shows the processing route of two-stage roughing, single-stage scavenging, and three-stage cleaning; TRTSTC involves two-stage roughing, two-stage scavenging, and three-stage cleaning; RGTRTSTC involves twostage roughing, two-stage scavenging, and three-stage cleaning after the regrinding of copper rough concentrate).

a)

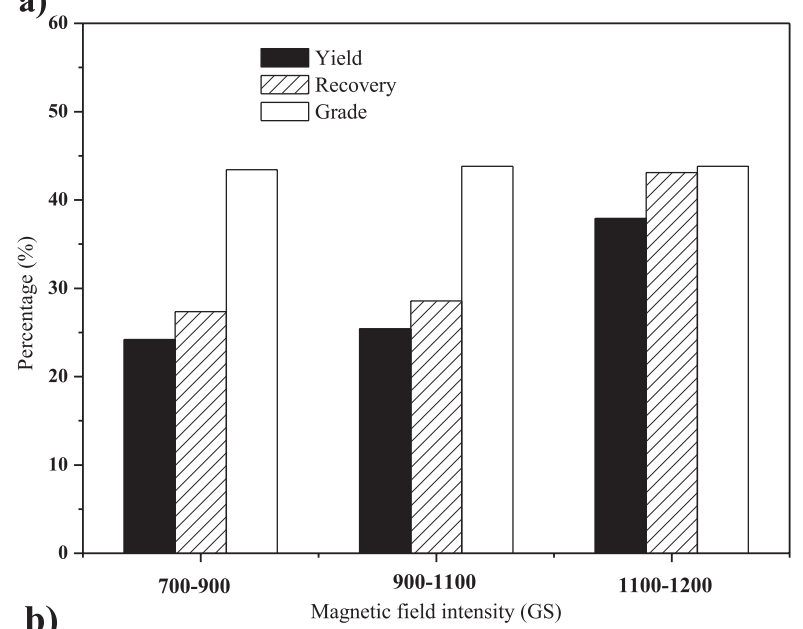

b)

Magnetic field intensity (GS)

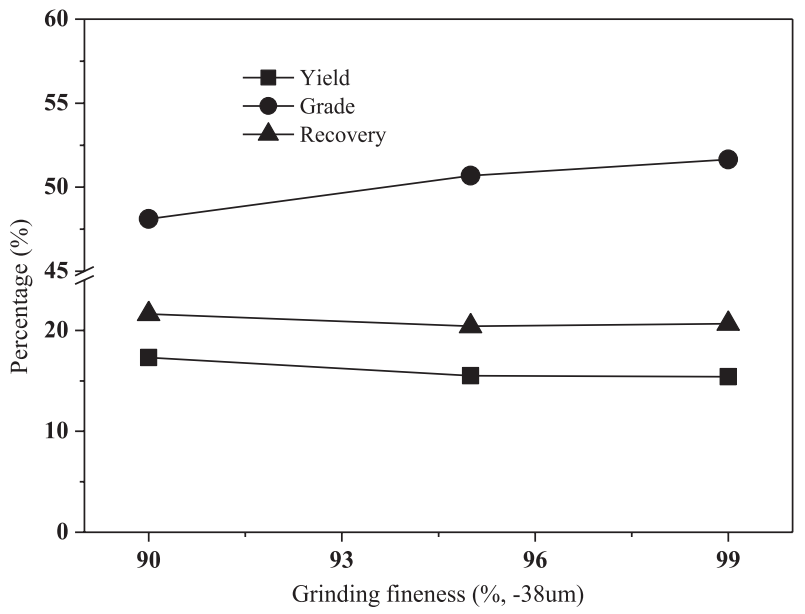

Fig. 6. Effects of condition parameters for the recovery of iron from CEFS flotation tails a) effect of magnetic intensity for iron roughing process; $b$ ) effect of regrinding fineness of rough concentrate for iron cleaning. by CEFS flotation of this study were $19.86 \%$ and $72.79 \%$, respectively. The results show Level 3 standard (20\% of grade) of copper concentrate quality standard (YS/T 318-2007).

\section{Characteristics of Copper Concentrates and Flotation Tailings}

To evaluate the efficiency of this proposal on copper flotation process, the mineralogical characteristics of CEFS flotation concentrates and tailings were investigated. The results show that $98.71 \%$ copper in copper concentrates exists in the form of copper sulfide and copper alloy. However, the copper concentrates still contain a large number of impurity minerals because a part of copper sulfide is still present as interlocking or inclusion in fayalite, magnetite, and pyroxene. Most of the impurity minerals were not liberated unless the grinding degree is less than $10 \mu \mathrm{m}$. Magnetite $(12.13 \%)$, fayalite $(42.82 \%)$, and pyroxene $(40.26 \%)$ are the main minerals of flotation tailings and also contain a small amount of copper sulphide $(2.45 \%)$ and ferroalloys $(1.02 \%)$. These indicate that the proposed flotation process is a feasible method to recover cooper from CEFS. Magnetite is difficult to
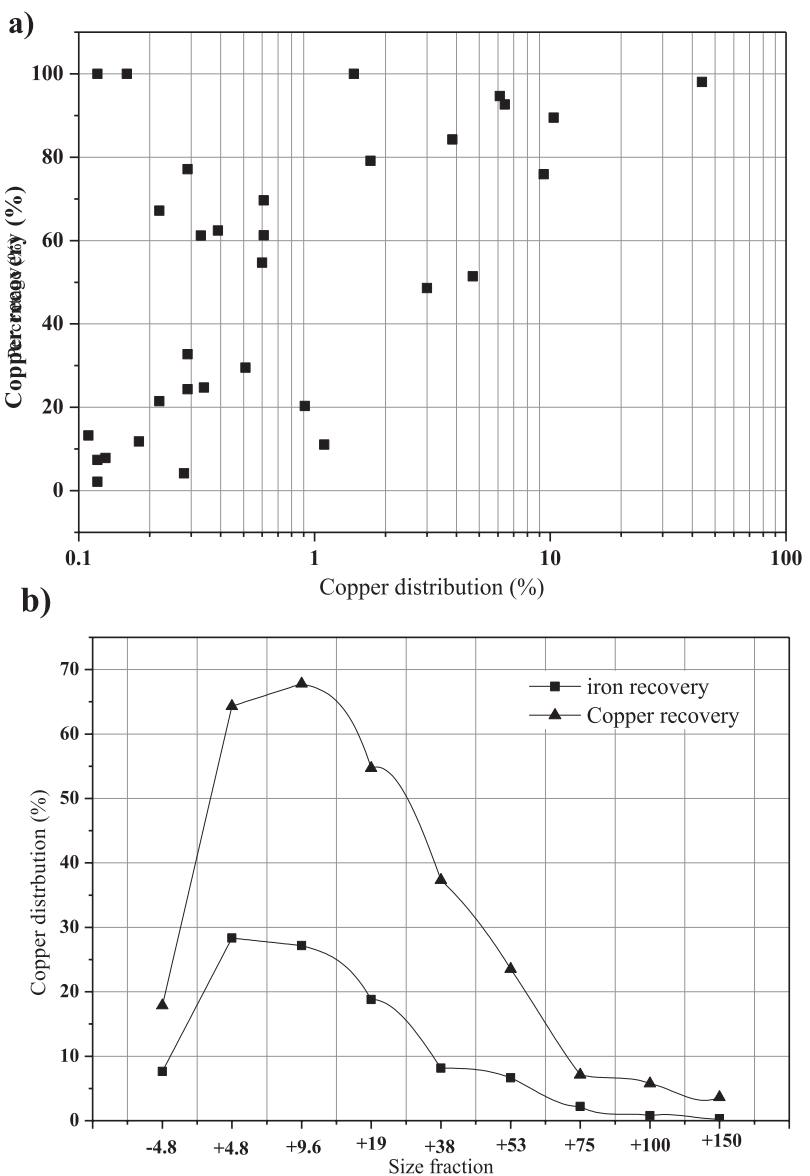

Fig. 7. a) Relationship between copper distribution and copper recovery by flotation separation; b) average size by copper and iron recovery $(90 \%,-48 \mu \mathrm{m})$. 


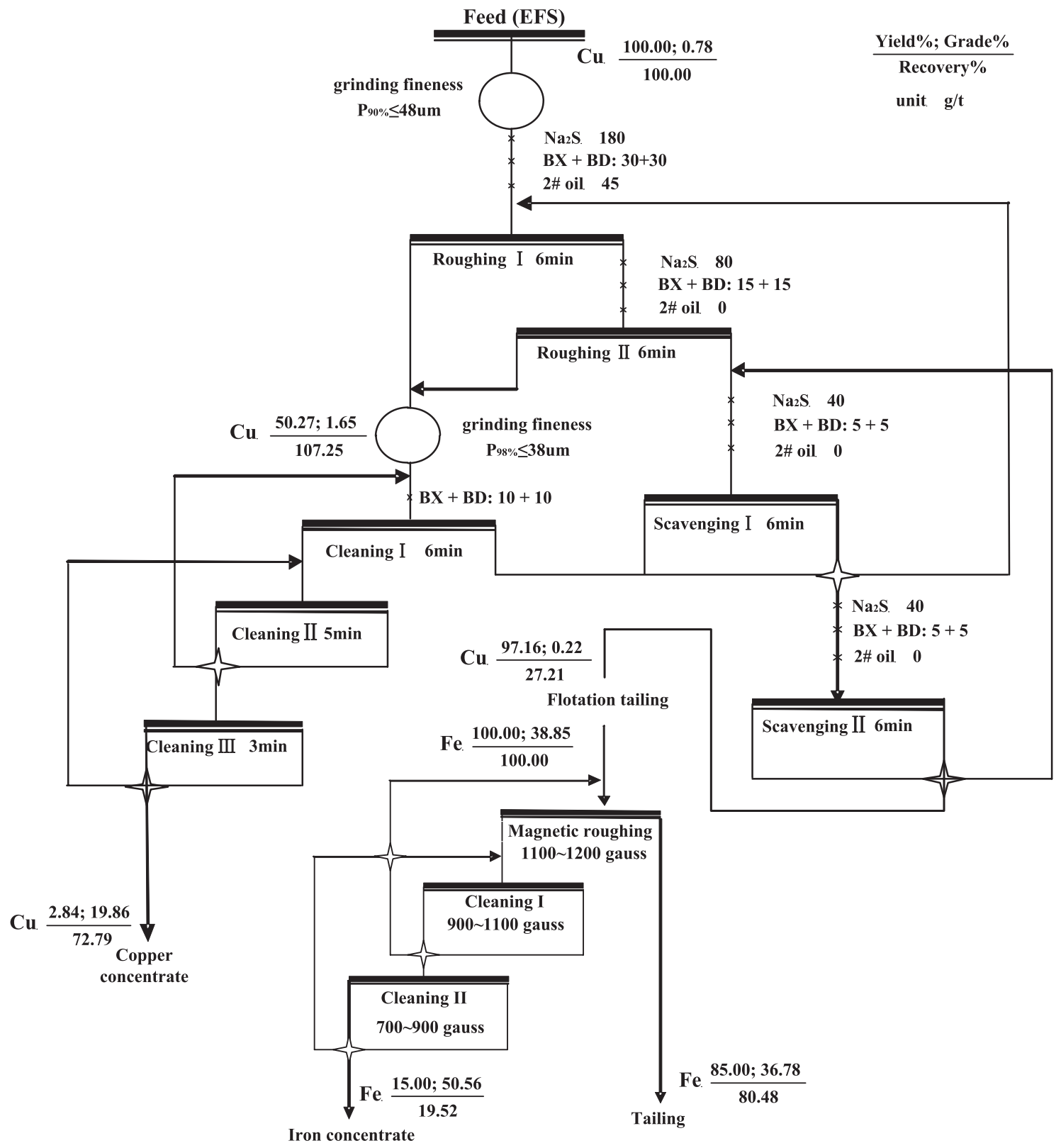

Fig. 8. Flowsheet and optimal process parameters of recycle copper and iron from CEFS.

float during copper floatation. Only a small amount of magnetite is added to copper concentrates because it cannot be liberated with copper sulphide. This indicates that it does not significantly affect the recovery rate and grade of recycled iron by magnetic separation followed by copper recovery by floatation.

\section{Iron Magnetic Separation Studies}

The mineralogical characteristics show that it is feasible to recycle iron from CEFS flotation tailings by magnetic separation and has a collection value. After filtration and drying, the flotation tailings act as samples for magnetic separation tests. The effect of main condition parameters for recycling iron is shown in Fig. 6. Fig. 6a) shows that increasing the magnetic intensity of roughing process of iron magnetic separation can increase the recovery rate of iron and guarantee that the iron grade does not change significantly. Fig. 6b) shows that the iron grade is affected by regrinding significantly and increases by about $5.32 \%$ when improving the regrinding fineness to achieve $(95 \%,-38 \mu \mathrm{m})$. In addition, two-stage cleaning is conductive to iron recycling, and the optimal magnetic intensities of iron cleanings I\# and II\# were 900-1100GS and 700-900GS, respectively. This indicates that the optimal iron magnetic processing routes from CEFS flotation tailing is single-stage roughing and two-stage cleaning of iron rough concentrate after regrinding. The flowsheet and parameters are shown in Fig. 8. The iron grade and recovery of iron concentrates of this study are $50.69 \%$ and $20.41 \%$, respectively. 
Table 6. Main reference indexes of financial statistical analysis.

\begin{tabular}{|c|c|c|c|c|}
\hline Index & Quantity (t/a) & Unit price (yuan/t) & Total investment (million yuan) & Unit cost (yuan/t) \\
\hline CEFS & 231000.00 & -- & \multirow{4}{*}{$¥ 6.53021$} & \multirow{4}{*}{$¥ 901.7$} \\
\hline Copper concentrate & 6560.40 & $¥ 6591.00$ & & \\
\hline Iron concentrate & 33665.94 & $¥ 404.00$ & & \\
\hline Tailings & 190773.66 & $¥ 40.00$ & & \\
\hline
\end{tabular}

\section{Mineral Balance Analysis}

The relationship between copper distribution and copper recovery by flotation separation is shown in Fig. 7a). The main copper-containing minerals with copper distribution larger than 5\% have a high copper recovery and vice versa. Fig. 7b) shows the average size by copper and iron recovery. Both metals show the classic size by size recovery curve as reported by Trahar et al [35-36]. The maximum recovery was achieved in the intermediate size fractions $(+4.8-53 \mu \mathrm{m})$, and the coarse $(+53 \mu \mathrm{m})$ and fine $(-4.8 \mu \mathrm{m})$ particles were recovered at a lower rate. The recovery peaks of copper are located in the $4.8 \mu \mathrm{m}$ to $38 \mu \mathrm{m}$ size range, while those of iron are located in the size range from $4.8 \mu \mathrm{m}$ to $19 \mu \mathrm{m}$. These phenomena are consistent with the mineralogical characteristics of CEFS.

\section{Engineering Project and Efficiency Analysis}

The research achievements of this study were applied in a copper smelter of Yunnan Copper Co., Ltd., China. In each year, approximately 0.231 million tons of abandoned CEFS is generated from their copper pyrometallurgical processes. Based on this study, the design scale of slag-dressing plant is 700 tons of CEFS per day. The technological processes consist of slow cooling, crushing, grinding, copper flotation, and wet iron magnetic separation. The mineral processing flowsheet is shown in Fig. 8. The production includes copper concentrates, iron concentrates, and tailings. The main reference indexes of financial statistical analysis are shown in Table 6. The financial analysis results show that this is a profitable project, and the net profit is $¥ 19.1452$ million yuan per year. After tax deduction, the finance internal return rate and investment recovery period were $34.95 \%$ and 3.86 years (including construction period of 1.0 year), respectively. In addition, it can provide about 60 new employment opportunities to alleviate the employment pressure of society and drive the development of tertiary industry, such as transportation and service. Finally, it has great environmental benefits and can reduce the discharge of copper slag (about 231,000 tons per year), recycle metallic copper (about 1300 tons per year) and iron (about 17000 tons per year), save mineral resources, and reduce about 2 hectares of land occupation due to the stacking of CEFS.

\section{Conclusions}

Recovery of copper and iron from CEFS using a physical separation process was investigated. The main mineral compositions of CEFS are pyroxene, fayalite, magnetite, and copper sulphide. Copper is mainly distributed in chalcopyrite, copper matte, and bornite, while iron is distributed in fayalite, magnetite, and pyroxene in CEFS. Copper sulfide and magnetic iron (including magnetite and ferroalloy) account for $85.88 \%$ and $26.53 \%$ of total copper and iron and can be recycled by flotation and magnetic separation, respectively. Copper sulfide and magnetite are the main interlocking and inclusion substances in pyroxene, fayalite, and each other. It is feasible to recycle iron by a combined process of magnetic separation from flotation tailings after the recovery of copper by CEFS flotation. The proposed process involves the following stages: (a) crushing and grinding CEFS to achieve $(90 \%,-48 \mu \mathrm{m})$, (b) copper flotation recovery from CEFS at the optimum processing routes, and (c) iron magnetic recovery from CEFS flotation tailings at the optimal magnetic separation routes. Under the optimal conditions, the recoveries of copper and iron of this study are $72.79 \%$ and $20.41 \%$, respectively, and the grades of copper and iron concentrates are $19.86 \%$ and $50.69 \%$, respectively. The research achievements of this study were used in engineering applications successfully in a copper smelter of Yunnan, China. This clearly proved that it is feasible to recover copper and iron from CEFS via a combined process of flotation and magnetic separation with significant economic, social, and environmental benefits.

\section{Acknowledgements}

This study was supported by the National Natural Science Foundation of China (41701362, 51768074) and Natural Science Foundation of Yunnan Province (2018FD020).

\section{Conflict of Interest}

The authors declare no conflict of interest. 


\section{References}

1. GORAI B., JANA R.K. Characteristics and utilisation of copper slag-a review. Resour. Conserv. Recy. 39 (4), 99, 2003.

2. SHI C., MEYER C., BEHNOOD A. Utilization of copper slag in cement and concrete. Resour. Conserv. Recy. 52 (10), $1115, \mathbf{2 0 0 8}$

3. MURARI K., SIDDIQUE R., JAIN K.K. Use of waste copper slag, a sustainable material. J. Mater. Cycles Waste. 17 (1), 13, 2015.

4. YANG Z.H., QIAO L., LU S.C., YONG H., LIAO G.D., YI K. Effect of $\mathrm{CaO} / \mathrm{SiO}_{2}$ ratio on the preparation and crystallization of glass-ceramics from copper slag. Ceram. Int. 40 (5), 7297, 2014.

5. KIM B.S., JO S.K., SHIN D., LEE J.C., JEONG S.B. A physico-chemical separation process for upgrading iron from waste copper slag. Inter. J. Min. Process. 124, 124, 2013.

6. SHEN H.T., FORSSBERG E. An overview of recovery of metals from slags. Waste Manage. 23 (10), 933, 2003.

7. LI Y., CHEN Y.M., TANG C.B., YANG S.H., HE J., TANG M.T. Co-treatment of waste smelting slags and gypsum wastes via reductive-sulfurizing smelting for valuable metals recovery. J. Hazard. Mater. 322, 402, 2017.

8. CAO H.Y., WANG J.M., ZHANG L., SUI Z.T. Study on green enrichment and separation of copper and iron components from copper converter slag. Procedia Environ. Sci. 16, 740, 2012

9. HU J.H., WANG H., ZHAO L.M., LI L., LIU H.L. Characterization of copper slag from impoverishment. J. Safety Environ. 11 (2), 90, 2011 [In Chinese].

10. ZUO Z.L., YU Q.B., WEI M.Q., XIE H.Q., DUAN W.J., WANG K., QIN Q. Thermogravimetric study of the reduction of copper slag by biomass. J. Therm. Analy. Calor. 126 (2), 481, 2016.

11. RAJ S., RAI A.K., HAVANAGI V.G. Suitability of stabilized copper slag and fly ash mix for road construction. World J. Eng. 15 (3), 336, 2018.

12. SARFO P., DAS A., WYSS G., YOUNG C. Recovery of metal values from copper slag and reuse of residual secondary slag. Waste Manage. 70, 272, 2017.

13. LIDELÖW S., MÁCSIK J., CARABANTE I., KUMPIENE J. Leaching behaviour of copper slag, construction and demolition waste and crushed rock used in a full-scale road construction. J. Environ. Manage. 204 (1), 695, 2017.

14. PANDA S., MISHRA S., RAO D.S., PRADHAN N., MOHAPATRA U., ANGADI S., MISHRA B.K. Extraction of copper from copper slag: Mineralogical insights, physical beneficiation and bioleaching studies. Korean J. Chem. Eng. 32 (4), 667, 2015.

15. MOMBER A.W., MARQUARDT T. Statistical investigations into the flow of copper slag abrasive particles through a blast-cleaning metering system. Powder Technol. 301, 179, 2016

16. ZHOU S.W., WEI Y.G., SHI Y., LI B., WANG H. Characterization and recovery of copper from converter copper slag via smelting separation. Metall. Mater. Trans. 49 (5), 2458, 2018.

17. LI L., WANG H., HU J.H., LI B. Study development of the comprehensive utilization of copper slag. Energy Metall. Indus. 28 (1), 44, 2009 [In Chinese].

18. KAKSONEN A.H., SÄRKIJÄRVI S., PEURANIEMI E., JUNNIKKALA S., PUHAKKA J.A., TUOVINEN O.H.
Metal biorecovery in acid solutions from a copper smelter slag. Hydrometallurgy 168,135, 2017.

19. VESTOLA E., KUUSENAHO M., NÄRHI H., TUOVINEN O., PUHAKKA J., PLUMB J. Acid bioleaching of solid waste materials from copper, steel and recycling industries. Hydrometallurgy 103 (1), 74, 2010.

20. TURAN M.D., SARI Z.A., DEMIRASLAN A. Ultrasound-assisted leaching and kinetic study of blended copper slag. Metall. Mater. Trans. B 50 (14), 1, 2019.

21. PARAONS M.B., BIRD D.K., EINAUDI M.T., ALPERS C.N. Geochemical and mineralogical controls on trace element release from the Penn Mine base-metal slag dump, California. Appl. Geochem.16 (14), 1567, 2001.

22. ALTER H., The composition and environmental hazard of copper slags in the context of the basel convention. Resour. Conserv. Recy. 43 (4), 353, 2005.

23. QIN W.Q., WANG P.P., REN L.Y., WEI Q., PENG Z.B., GU Y.L. Effect of matching relationship between particles and bubbles on the flotation of fine cassiterite. J. China Univ. Min. Tech. 41 (3), 420, 2012 [In Chinese].

24. CARRANZA F., IGLESIAS N., MAZUELOS A., ROMERO R., FORCAT O. Ferric leaching of copper slag flotation tailings. Min. Eng. 22, 107, 2009.

25. ZHANG Y., MAN R.L., NI W.D., WANG H. Selective leaching of base metals from copper smelter slag. Hydrometallurgy, 103 (1-4), 25, 2010.

26. BAGHALHA M., PAPANGELAKIS V.G., CURLOOK W. Factors affecting the leachability of $\mathrm{Ni} / \mathrm{Co} / \mathrm{Cu}$ slags at high temperature. Hydrometallurgy, 85 (1), 42, 2007.

27. LI Y.J., PAPANGELAKIS V.G., PEREDERIY L. High pressure oxidative acid leaching of nickel smelter slag: characterization of feed and residue. Hydrometallurgy, 97 (3), 185, 2009.

28. KAKSONEN A.H., LAVONEN L., KUUSENAHO M., KOLLI A., NÄRHI H., VESTOLA E., TUOVINEN O.H. Bioleaching and recovery of metals from final slag waste of the copper smelting industry. Min. Eng. 24 (11), 1113, 2011.

29. LI B., WANG X.B., WANG H., WEI Y.G., HU J.H. Smelting reduction and kinetics analysis of magnetic iron in copper slag using waste cooking oil. Scientific Reports, 7 (1), 2406, 2017

30. ARSLAN C., ARALAN F. Recovery of copper, cobalt, and zinc from copper smelter and converter slags. Hydrometallurgy, 67 (1), 1, 2002.

31. ZHANG Y., WANG Y.H., LI S.L. Flotation separation of calcareous minerals using didodecyldimethylammonium chloride as a collect. Inter. J. Min. Sci. Tech. 22 (2), 285, 2012.

32. SONG W., LIU X.L. Study on copper concentrating from converter slag of copper smelter. Nonferrous Metals, 53 (3), 78, 2001 [In Chinese].

33. DWARI R.K., RAO D.S., REDDY P.S.R. Magnetic separation studies for a low grade siliceous iron ore sample. Inter. J. Min. Sci. Tech. 23, 1, 2013.

34. 3ZHANG H.X. Discussion on slow cooling process of copper smelting slag. China Nonferrous Metallurgy, 42 (3), 32, 2013 [In Chinese].

35. YIANATOS J., CONTRERAS F. Particle entrainment model for industrial flotation cells. Powder Technol. 197 (3): 260, 2010.

36. TRAHAR W. A rational interpretation of the role of particle size in flotation. Int. J. Miner. Process. 8 (4), 289, 1981. 